\title{
The Communication Process in Tribal War Tradition in Timika, Papua, Indonesia: A Symbolic Interaction Perspective
}

\author{
Dr. Wawan Lulus Setiawan \\ Associate Professor of Indonesia Institute of Cooperative Management (IKOPIN)
}

\begin{abstract}
Indonesia is a large and socially heterogeneous country because it covers more than 1,340 ethnic groups. The country is rich of various cultural traditions. The diversity of cultural traditions in Indonesia is interestingly studied both as a material of scientific study and as an source to formulate appropriate socio-economic development policy approaches. One of the regions/islands in Indonesia is Papua, which is located in the eastern part of Indonesia. In this region there are more than 500 ethnic groups. Ethnic groups in Papua, is the most traditional ethnic group compared to those in Indonesia. One tradition that is still strongly held in Papua is tribal war. Therefore it is a very interesting phenomenon studied in terms of social science, especially communication science. The symbolic interactionism perspective as a communication approach is used in this study to explain how the communication process occurs in traditional war process between tribes, both in the internal communication of tribes and communications between tribes. This study describes the phenomenon of war between tribes according to the view or the consciousness and subjective meaning of traditional/indeginuous people in Timika, in accordance with the phenomenology tradition that is used in this research. The findings of this study are illustrates the process of communication, beginning from preparation of war, the implementation of war, as well as post-war process. Communication processes that occur either through verbal or non-verbal language are full of distinctive symbols. The conclusion of this finding is that tribal war as a social phenomenon is a communication process, and can be solved by the parties by means of communication. These findings could have implications for the importance of policies to develop communication approaches among traditional tribes in Papua, in order to increase the understanding among them, which in turn will reduce the level of conflict between them.
\end{abstract}

Keywords: symbolic- interactionism, tribal-war, Papua

\section{Introduction}

\section{Background}

Indonesia is a large and socially heterogeneous country because it covers more than 1,340 ethnic groups. The country is rich of various cultural traditions. The diversity of cultural traditions in Indonesia is interesting to study both as a subject of scientific study and as a consideration to formulate appropriate socio-economic development policy approaches. One of the regions / islands in Indonesia is Papua, which is located in the eastern part of Indonesia. In this region there are more than 500 ethnic groups. Ethnic groups in Papua, is the most traditional ethnic ones compared to others in Indonesia. One tradition that is still held in Papua is tribal war. This tradition still exists in Papua, therefore it is a very interesting phenomenon to study in terms of social science, especially communication science.

One of the locations and community groups studied in this research is the seven tribal communities in Timika, Papua. In the traditional seven-tribal societies of Timika Papua, inter-ethnic war can be said to be part of their tradition and as part of their way of "solving" problems among different ethnic communities. In Timika, there are currently seven tribes that are recognized as residents of Mimika Regency, namely: Dani, Amungme, Kamoro, Moni, Damal, Ekari, and Mee. Of the seven tribes, in fact, the original tribe of Mimika Regency is only two tribes, namely Amungme and Kamoro. The other five tribes are migrants from neighboring areas of Mimika Regency. 
One example of a tribal war case in Timika was a tribal war that occurred in March 2007, placed in Kwamki Lama Timika. This tribal war is quite large because it involves 2,000 citizens. This war occurred between the Dani tribe against the Damal tribe, but in its expansion also involves the Amungme and Moni Tribe. The impact of this war, died 18 people and injured 300 people. However, since the war has become a tradition of tribal peoples in Timika, tribal wars often occur. The last tribal war occurred at the end of 2016 triggered by land issues.

The process of communication in traditional war as a social process is in fact closely related to the culture of society itself, therefore the symbols used in the communication process cannot be separated from the symbols of their culture. The relationship between communication and culture is a very complex and intimate one. First, cultures are created through communication; that is, communication is the means of human interaction through which cultural characteristics, roles, rules, rituals, laws, or other patterns-are created and shared. Culture and communication have been defined and re-defined repeatedly, as are intrinsically human (Garcia-Carbonell, A. and Rising, B, 2006: 1).

The approach of symbolic interactionism as a communication approach can be used to explain how the interaction process occurs in the traditional war process between the tribes, both in the internal communications of tribes and communications between warring tribes, starting from the preparation of war, the implementation of war, and post-war divorce process. The process of communication that occurs either through verbal or non-verbal language is interesting to be studied because it is full of distinctive symbols

\section{State of The Art}

This state of the art includes, the expected output and focus of the study, the conceptual framework of the study, and the methods undertaken.

\section{a. Expected output and focus of the study}

This study is aimed at revealing the communication process in Timika from the perspective of symbolic interactionism. The inter-ethnic war is full of verbal and non-verbal communication symbols. The uniqueness of symbols and what its meaning is for the warring all parties in war is interesting to reveal.

\section{b. Conceptual Framework}

This study tries to describe the phenomenon of inter-etnic war according to the view or the consciousness and subjective meaning of the actors of war in Timika, the tradition used in this research is the phenomenology. The term phenomenology can be used as a generic term to refer to all social science views that place human consciousness and its subjective meaning as the focus for understanding social action, such as Max Weber's views, Charles Horton Cooley, George Herbert Mead, William I Thom, Alferd Schutz, George Simmel, Herbert Blummer, Erving Goffman, Peter L. Berger, Thomas Luckman and the psychologists Carl Rogers, Abraham Maslow and Erich Fromm (Mulyana, 2001: 20-21).

Phenomenological approaches is categorized to subjective or interpretive approaches, which view humans as active, in contrast to objective approaches or behavioristic and structural approaches that assuming humans are passive (Mulyana, 2001: 59). Phenomenology makes actual lived experience of the basic data of reality (Littlejohn, 1996: 204). Phenomenology means letting everything become real as it is, without forcing the categories of researchers against it. An objective scientist hypothesized a particular structure and then examined whether such a structure exists, a phenomenologist never hypothesized, but thoroughly investigated the real direct experience to see how it seems (Kuswarno, 2007)

There are two main approaches in the phenomenology tradition: symbolic interactionism and ethno-methotology (Bogdan \& Taylor, 1975). Symbolic interaction, also known as one of communication science perspective, becomes the foundation of thought and analysis in this research. Symbolic interaction contains the basic core of the premise of communication and society.

Symbolic interactionism studies the nature of interactions that are dynamic human activities, in contrast to structural approaches that focus on the individual and his personality traits, or how social structures shape certain individual behaviors. The symbolic interaction perspective sees that individuals are active, reflective and creative, interpreting, displaying complex and unpredictable behaviors. This belief rejects the idea that the individual is a passive organism whose behavior is determined by forces or structures outside of himself. Because individuals are constantly changing, society 
changes through interaction. So interaction is considered an important variable that determines human behavior, not the structure of society. The structure itself is created and changed by human interaction, ie when individuals think and act stably against the same set of objects (Mulyana 2001: 62)..

Reviewing the communication process from the perspective of symbolic interaction in tribal war in Timika is inseparable from the verbal and nonverbal symbols that are at the core of communication, since communication will never take place if no symbols are exchanged. In other words, this study discusses the behavior of communications (the use of the symbol of communication) in a phenomenological perspective.

Verbal communication encompasses any form of communication involving words, spoken, written or signed. Verbal communication coexists alongside non-verbal communication, which can affect people's perceptions and exchanges in subtle but significant ways. Non-verbal communication includes body language, such as gestures, facial expressions, eye contact and posture. The sound of our voice, including pitch, tone and volume are also forms of non-verbal communication. The clothing we wear and the way we design our living space are also forms of non-verbal communication that frequently shape people's judgments about others, regardless of whether or not the perceptions are true (Lucas, 2017)

In the science of communication, there is a study that is able to touch verbal and nonverbal communication in a holistic view, i.e. ethnographic study of communication. The ethnography of communication was introduced and developed by Dell Hymes. Hymes proposed the term 'ethnography of speaking', later amended to 'ethnography of communication', to describe a new approach to understanding language in use (Hymes, 1964). Essentially, Hymes argues that the ethnography of communication ... is concerned with the question of how to do it. (Farah, 1998: 125). The ethnography of communication views communication behavior as a behavior born out of the integration of skills that every individual has as a social being. These three skills consist of linguistic skills, interaction skills and cultural skills. In other words, ethnography of communication is a study that places the function of speaking in a sociocultural context (Suciasih, 2003)

In describing and analyzing communication behavior, ethnographic communication does so by analyzing acts of speech, which are at the core of communication events in certain situations. Speech that is the object of ethnographic communication research, according to Hymes is generally conterminous with a single interaction function, such as referential references, requests, orders, and nonverbal symbols (Ibrahim, 1992: 35-37).

Communication ethnography describes communication symbols as 'what' is exchanged as indicated in Table 1.

Tabel 1. Codes and Channel of Communication

\begin{tabular}{|l|l|l|l|}
\hline \multicolumn{2}{|c|}{} & Channel \\
\cline { 3 - 4 } Code & Vocal & Non-Vocal \\
\hline \multirow{2}{*}{ Verbal } & Oral-Language & $\begin{array}{l}\text { Written language } \\
\text { Sign language } \\
\text { Whistling language } \\
\text { Morse Code }\end{array}$ \\
\cline { 3 - 4 } & Non-Verbal & $\begin{array}{l}\text { Paralinguistic characteristis } \\
\text { and persoal characteristic } \\
\text { sign } \\
\text { eye movement } \\
\text { picture and cartoons }\end{array}$ \\
\hline
\end{tabular}

(Source: Ibrahim, 1992:217, translated)

\subsection{Methods of study}

\section{a. Location and subject of the study}

In accordance with the research topic on the communication of Tribal War Tradition in Timika, the research location is in Timika Papua. Timika is a regency capital named Mimika Regency. Geographically this district is located in the southern part of Papua province (see Figure 1). 
In this regency the location of mining contract work of PT. Freeport Indonesia is implemented. The existence of this mining contract also made Timika which in the 70 s only a small village that is very remote in Papua slowly but surely developed into a village in the 80 s then developed into the district in the 90 s, and has now become a regency

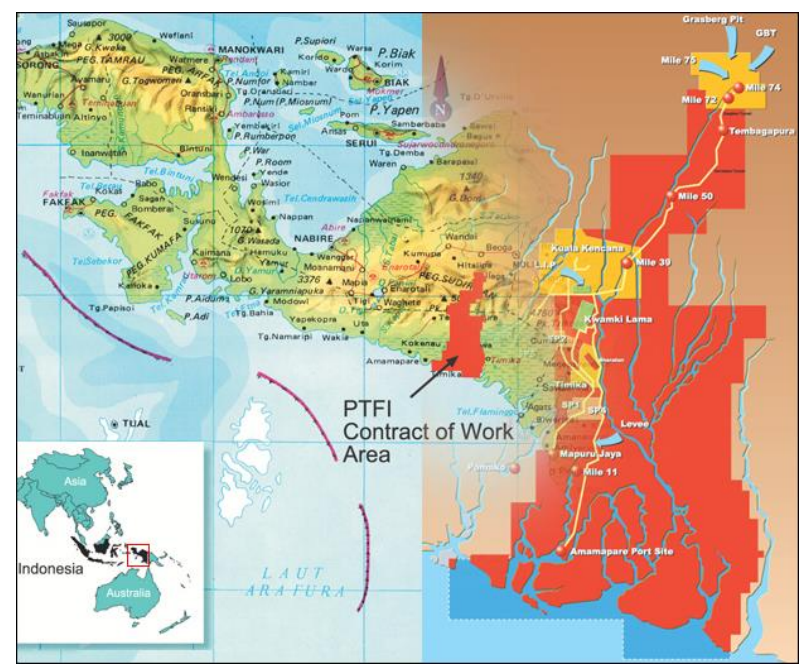

Figure 1. The map of study location

The indigenous people of the Mimika Regency, which used to be only two ethnic groups of the Kamoro tribe in the South Coast and Amungme Tribes domiciled in the northern mountains, increased by five tribes from neighboring districts. The immigrant tribes are Nduga, Moni, Mee, Dani and Damal. With the increasing number of tribes in Mimika regency then the complexity of the people in Mimika become more and more, and the chances of conflict become higher. Thus, tribal wars are often inevitable, even often a large-scale war.

Nevertheless, for traditional Papuan societies in general, tribal war is one of tradition or part of their lives, as part of their way of expressing their self-esteem and family attributes. With that background, then the subject of research on the study of tribal war are Papuans in Timika who became perpetrators in tribal wars in Timika

\section{b. Process of Approach and Determination of Informants}

What is meant by the process of approach here is what is meant by Creswell (1998: 130) as "gaining access and making rapport". Gaining closeness with community leaders, even tribal chiefs or warlords in Papua is not easy, as they generally have a high suspicion of 'foreign' people, especially those from outside of Papua whom they categorize as straight-haired people. This is understandable because they were raised in a society that has a tradition of tribal war, so caution, alertness, and suspicion of the 'foreigner' are always part of their already internalized way of life. But for me as the researcher, having worked as a Papuan development consultant in Timika since 1999, even living in Timika for three years (2001-2004), the proximity to the subject is no longer a problem, as the community leaders has become the 'care' of researchers.

In the study of phenomenology, the criteria of good informants are "all individuals studied represent people who have experienced the phenomenon" (Creswell, 1998: 118). Thus, in this study, the selected informant was actually a Papuan citizen in Timika who was a perpetrator of the tribal war . 


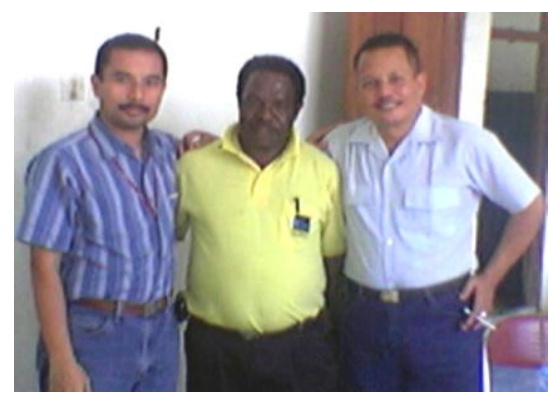

Figure 2. Taking ficture with Yacobus

Kogoya (the centre) Warlord of Dani

As for the number of informants selected, this study uses Creswell's (1998: 122) opinion as a methodological reference. Creswell stated "for a phenomenological study, the process of collecting information involves primarily in-depth interviews (see, e.g. the discussion about the long interview in McCraken, 1988) with as many as 10 individuals. I have seen the number of interviewees referenced in studies range from1 (Dukes, 1984) up to 325 (Polkinghorne, 1989). Dukes (1984) recommends studying 3 to 10 subjects, and Riemen (1986) study included 10. The important point is to describe the meaning of small number individuals who have experienced the phenomenon. With in-depth interview lasting as long as 2 hours (Polkinghorne, 1989)

10 subjects in a study represents a reasonable size.

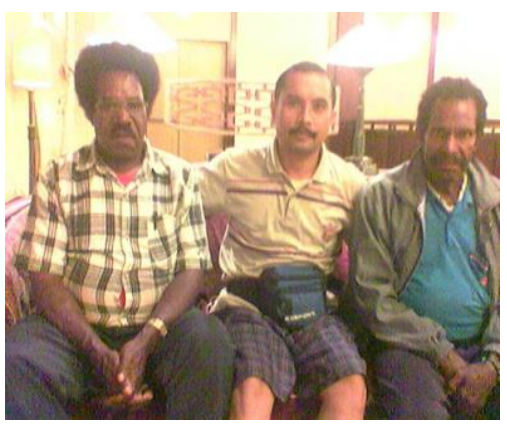

Figure 3. Taking picture with Aser Murib (left) warlord of Damal tribe

Based on Creswell's reference, in this study four tribal war perpretators in Timika Papua and 1 Timika resident as a witness to the incident were interviewed. The four tribal warriors in Timika are Moses Tsolme, Herminus Kogoya (Dani tribe, war strategy strategist), Aser Murib (Warlord of Damal Tribe), and James Kogoya (leader of the Dani tribe, commander of War of Dani), as shown on Figure 2, figure 3, and figure 4. These four men were the main actors in the tribal war tradition in Timika

\section{c. Techniques and Time of Data Collection}

This study was conducted from 2007 until 2017. At the time one of the largest tribal warfare occurred in March 200. The technique of data collection was interview technique. Interviews were conducted openly and unstructured in a free and relaxed atmosphere, documentation of interview results through audio tape recorder (tape recorder) and image recorder (digital camera). 
The most important of the interview process in the phenomenology study is the taking of informant data about their explanation of the life experience of a small number of informants. Interviews followed Moustakas' suggestion cited by Kuswarno in Mulyana and Solatun (2007) that "The phenomenological interview involves an informal, interactive process and utilizes open-ended comment and questions". Therefore, in this study as well as phenomenological research in general, in-depth interviews are the preferred data collection techniques. Therefore, with the community leaders, the interview process took place very easily and can be done anywhere depending on the agreement, in the hotel where researchers stay, in the car while walking to see the situation of the village community, or in the office company owned by them, even in their own homes

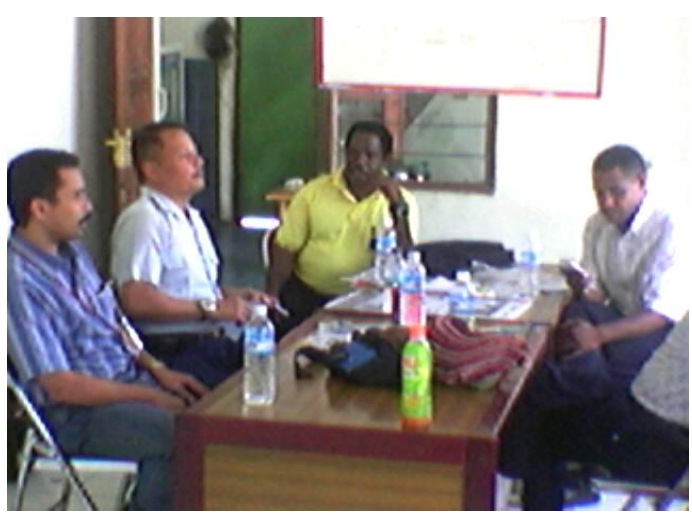

Figure 4. interviewing Yacobus Kogoya (third from lefti) and

Herminus Kogoya (right)

\section{Fact Finding and Result}

There are 2 (two) main findings of this research, namely (1) The meaning of war for the people of Timika, and (2) The process of tribal war that can be constructed as stages.

\section{a. The meaning of war for traditional Papuans in Timika}

For traditional Papuan societies in general, tribal war is one of tradition or part of their lives, as part of their way of expressing their self-esteem and family attributes. In addition, tribal wars mean solidarity as a family or a tribe. If one resident feels hurt or disturbed

In tribal wars, there are symbols that are full of meaning, could be consisting of clothing attributes, non verbal symbols either with movement or human voice. The symbols are attached to the activities of the war itself. Apart from that, in the tribal war, there have been organizational structures of war, the division of roles and rules/norms to be obeyed. One interesting feature of this traditional war is the "gentleman" attitude as part of the agreed rules in the relationship between the two hostile parties. This gentleman's attitude is characterized by the obedience of both parties to the rules of the game in war.

\section{b. Stages of war}

in this study, the tribal war in Timika can be constructed as a process consisting of several stages. This construction process is referred to as the ideal type of Weber, the construct of the second degree of Schutz, Grounded theory of Glaser, the second order concept of Denzin (see Mulyana, 2001)

In each of these steps, there is a communication process with distinctive symbols (symbolic interaction occurs). Stages with its communication process are described as follows 


\section{1) Stages of War Initiation}

The stage of war initiation is a condition of the emergence of triggering factors of war. The triggering factors of war may vary, among them most often arising from issues triggered by cases of rape, adultery, theft of pigs or murder. Once the trigger case occurs, the aggrieved (usually the closest of the family, his or her parents, her husband, her brother) will deliver a very emotional anger to her immediate family environment. Emotional expressions of words also appear, for example "the person must be killed" or "we must fight". So began the family "meeting" to realize his emotional will. The person who has the idea for battle is then called the "oknum" (Person). It is this person who then provokes the family of one tribe to fight

His initial provocation stage was to visit tribal chiefs and community leader in his tribe. He tried to convince in a fiery language that he himself, his family and his tribe had been offended, then the ransom had to fight. Thus, tribal chiefs and community leaders and individuals then held meetings to decide the war. The process of meeting was colored with a very emotional communication situation. Occasionally there are shouts that rekindle the spirit of war of all citizens who attended the meeting. After it was agreed to take a war decision, a war organization was formed: the War Tribal Chief, Warlord, Warrior and War Force/troops

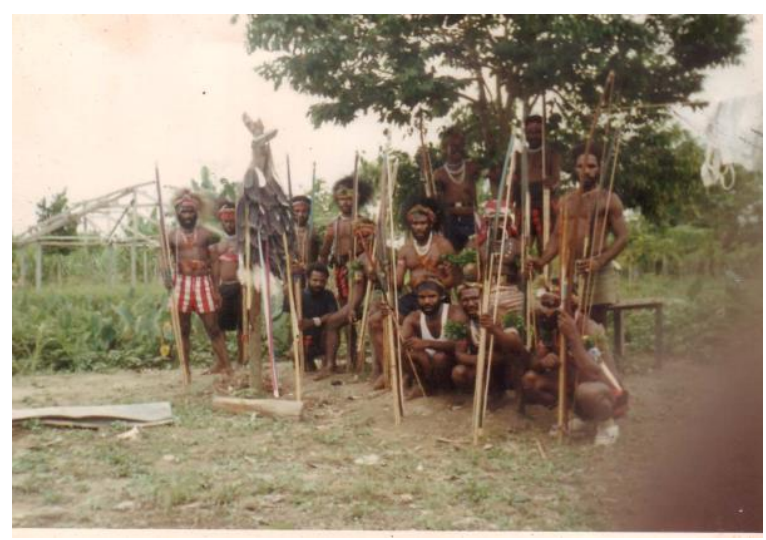

Figure 5. A group of war organization, chief of tribe, warlord, and troops.

Chief of Tribe is the highest level in a war organization, its job is to oversee all troop members. Warlord is the second tier, who is in charge of organizing a war strategy, including setting to the points where troops should move. The third level is "Oknum" (person), that is, people who have war or are exposed to issues that cause war (ilustrated in figure 5)

\section{2) Stage of Challenge Fight}




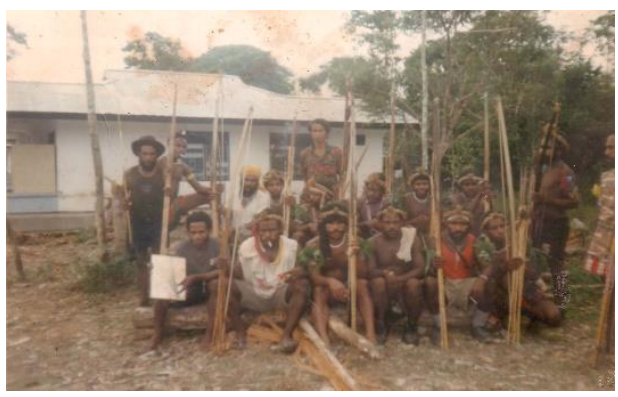

Figure 6. a group of people are standing by for

The stage of the war's challenge is the stage in which the party poses a challenge to fight the opponent. The challenge is done by way of coming to the opponent's location by grouping in a battle-ready dress. In an open space or field they gather together yelling out war chimes. The yells are, "I am a man, I am coming for war". Then together they yell "uuuu ... uuuu .... uuuu" with a typical high-pitched voice of the Papuan people. The opposite party usually has been prepared too with war alerts. So in that location the two concentration of people have faced to faced for the war ready period (Figure 6)

\section{3) Stage of war execution}

By the time the war is about to begin, both sides wear traditional "costumes" of war, ie clothing with koteka, with body and "Make Up" faces streaked in white. The goal is to disguise the face so it will not cause a grudge if the war is over. Weapons are usually in the form of arrows, spears, katepel and shield (protective equipment and weapons repellent)

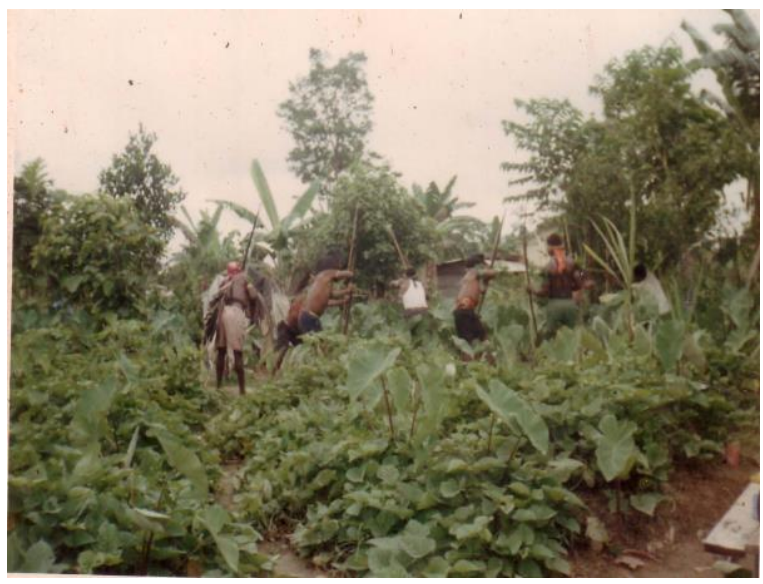

Figure 7. a group of war-force are implementing war startegy

War can begin if each of the hostile groups faces directly at a predetermined place and time. The usual place for war is an open place.

Before the war began usually each group shouts yell-yell of challenges war. Yell - yell is in their native language "I am a man, I come to war". Plus yell-shouts of war together "uuuu u uuu uuuu u" with the typical high-pitched voice of the Papuan people. There are also jelly-boosting tones and threats to the "person" or who have "war", for example, "Moses must be killed, not in the world!", If the person who became the person is named Moses. Yell-yell is always shouted during the war to encourage other members. If the atmosphere is heated, then their emotions are also provoked while throwing arrows or spears to their enemies If the war has occurred, then in this inter-tribal war there are rules that must be adhered to by both sides (Figure 7 and figure 8). 
These customary rules, among others:

(1) Women, children, elders, community leaders and priests should not be killed, so they are sometimes used as front armies.

(2) The war only takes place in an area that has been agreed, beyond that area there can be no war, because in case of murder outside the area of war will be a personal grudge and become his own business is not a matter of war;

(3) War must be open to face, do not play behind;

(4) Should not wear / carry firearms;

(5) There is an emergency rule of war, that is: it is permissible to steal and rape women but should not be taken unless it is to marry after the war, regardless of the widow's or virgin's status;

(6) Before the war ends it should not shake hands or feed one another or something to the enemy, because such a thing would be considered a betrayer worse to be killed by a friend of his own;

(7) During war there shall be no mention, other than signs or utterances commonly used as symbols of war;

(8) If a victim dies and an evacuation occurs, the opportunity shall not be used for attack by the enemy

War burns and heats up if a victim dies and continues to grow hot before the number of victims on both sides is equal (equal in number). Nevertheless each group is not afraid because of they perceived war is a game like football. In the battle, the members of troops always move left and right while squatting occasionally upward looking at the surrounding like a dancer, this is meant to avoid the attack of arrow or spear thrown by the opponent

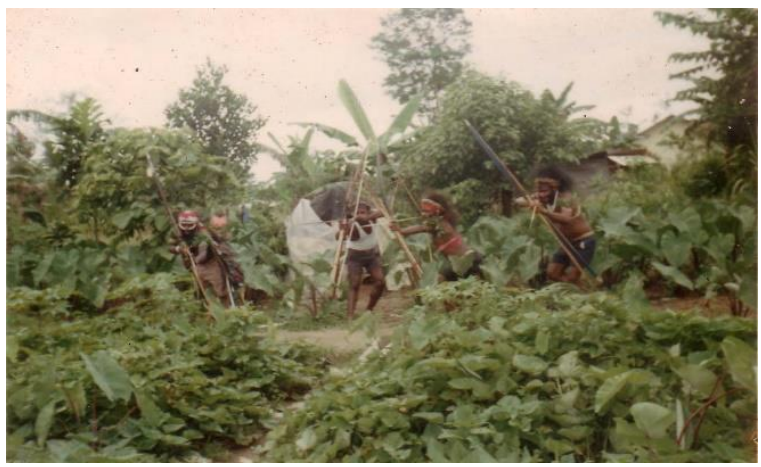

Figure 8. The execution of tribal war

Persons who rape women in the area of war should immediately get out of the battlefield and rest for 3 days, if not, his body will smell fragrant and hit by arrows

In the middle of the day, the pause war first begins with the shouting of "Uuuuu ...... uuuuuuu!" And must be known both sides. This break is used for rest and lunch purposes while counting the number of dead and wounded with arrows or spears. These rest periods are also used for shopping as a war logistics necessity, as items including pigs or others outside the war area should not be stolen and women should not be raped. In logistical warfare is left to the women of each group. If the break time is over, then the war can resume after a shouting sign: "Uuuuu ...... uuuuuuu!", and should be known by both parties as well.

If a troop sees on the opposite side there is a brother who is being targeted, then he will release an arrow right in front of his brother's face. It was a sign that his brother was being targeted and had to get out of the war area, if he did not get out soon, he would be the target of shooting arrows and be the victim 
In a group of warfare there is a pre-established organization, including: War Tribal Chief, War Commander, Person (person having war). The rank of rank in war is indicated by pig piercing in the nose, the longer the fangs are attached, the higher the rank. There is also a member of the troops assigned to give the code of the situation, he did not bring an arrow but only brought cassowary and spear fur. If the cassowary feathers are fanned upwards it means that there are enemies around us, then the troops should be down but if the spear is held up it means we are safe, then the troops can go on. At night the troops can rest for sleep, during this break the guarding of each group is tightened to keep the rigging of the opposing party whether it is infiltration, theft etc.

\section{5) Stage of Divorce War}

At this stage female figure play a role as mediator for war not to enlarge. Selected one of the female figure is not only play a role in these conditions but also serves as a medium of communication between groups so that other citizens of each party do not enter the area of war. The war will end if the death toll is equal (equal) on both sides previously characterized by the emergence of the elderly public figure for peace.

\section{6) Stage of Peace}

The peace of both sides is marked by a stone-burning ceremony synonymous with "thanksgiving". The ceremony is actually burning pigs piled with hot stones that are burned first while collecting donations from the community for "Pay Heads". Pork that has been cooked and then eaten together. If this ceremony is done the war is over.

\section{7) Stage of Head-pay}

Head-pay is a post-war tradition that is intended to pay compensation to the families of victims in the war. This is done by each of the hostile groups. The process of paying the head is done at the place agreed by both parties. it is usually done in public and open place, which is marked by greeting each other and hand over the goods as a pay-off tool

One head is worth Rp. 300 million. Payments can be made by cash, pigs or with similar "kewuk" shells called bia skin or "Kulum Bia". This type of shell is very valuable, but not all bia skins have a high customary value. Only bia skins have an "ear" has high-value. People who have skin bia are respectable in adat/norms. Skin bia always sought by customary leaders because it is easily exchanged for cash

Bia skin price can reach Rp. 150 million per one rope strand, one rope consists of 5 skins bia. The proceeds of the headpay were then handed over to the families of the victims, from the families of the victims then distributed again to their extended families, especially those who participated in the war.

\section{Conclusion and recommendation}

This study on tribal war in Timika concludes as follows:

1) The meaning of tribal warfare For Timika people: As a way they express self-esteem and family attributes, and solidarity as one family or one tribe (if one person feels hurt or disturbed).

2) In tribal war, there are symbols that are full of meaning, such as clothing attribute, non verbal symbol either with movement or human voice. The symbols are attached to the activities of the war itself. Apart from that in the tribal war, although traditionally there has been an organizational structure of war, the division of roles and rules / norms to be adhered to.

3) Tribal wars in Timika can be constructed as a process consisting of several stages. In each of stage there is a communication process with distinctive symbols. Stages with its communication process are described as follows:
a. Stages of War Initiation
b. Stage of Challenge Fight
c. Stage of War Implementation
d. Stage of Divorce War
e. $\quad$ Stage of Peace 
f. Stage of Head-pay

4) Tribal war as a social phenomenon is a communication process, and can be solved by the parties by means of communication. These findings could have implications for the importance of policies to develop communication approaches among traditional tribes in Papua, in order to increase mutual-understanding among them, which in turn will reduce the level of conflict among them.

\section{References:}

[1] Bogdan, Robert \& Steven j. Taylor, 1975. Introduction to Qualitative Research Methods: A Phenomenological Approach to the Social Sciences. In Kuswarno, Engkus. 2004. Dunia Simbolik Pengemis Kota Bandung, Studi tentang Konstruksi Sosial dan Manajemen Komunikasi Pengemis di Kota Bandung. Disertasi Program Pasca Sarjana Universitas Padjadjaran. Bandung. pp: 82.

[2] Creswell, John W. 1998. Qualitative Inquiry and Research Design : Choosing Among Five Traditions. Thousand Oaks: Sage;

[3] Farah, I. 1998. The Ethnography of Communication. In Johnstone, Barbara and Marcellino, William. 2010. Dell Hymes and the Ethnography of Communication. Carnegie Mellon University Research Showcase @ CMU. Department of English Dietrich College of Humanities and Social Sciences

[4] Garcia-Carbonell, A. And Rising, B, 2006. Culture and communication. Georgia: College of Management Georgia Institute of Technology Atlanta, Georgia, USA

[5] http://encyclopedia.jrank.org/articles/pages/6491/Culture-and-Communication.html. retrieved 3 September 2017

[6] Hymes, D. H. (ed.) (1964) Language in culture and society: A reader in linguistics and anthropology. In Johnstone, Barbara and Marcellino, William. 2010. Dell Hymes and the Ethnography of Communication. Carnegie Mellon University Research Showcase @ CMU. Department of English Dietrich College of Humanities and Social Sciences

[7] Ibrahim, Abd. Syukur. 1992. Panduan Penelitian Etnografi Komunikasi. Surabaya: Usaha Nasional.

[8] Kuswarno, Engkus. 2007. Dunia Simbolik Pengemis Kota Bandung, Studi tentang Konstruksi Sosial dan Manajemen Komunikasi Pengemis di Kota Bandung. In Mulyana, Deddy dan Solatun. 2007. Metode Penelitian Komunikasi, Bandung. Remaja Rosdakarya;

[9] Kuswarno, Engkus. 2004. Dunia Simbolik Pengemis Kota Bandung, Studi tentang Konstruksi Sosial dan Manajemen Komunikasi Pengemis di Kota Bandung. Disertasi Program Pasca Sarjana Universitas Padjadjaran. Bandung

[10] Littlejohn, Stephen W. 1996. Theories of Human Communication. Edisi ke-5. Belmont California: Wadsworth

[11] Lucas, Amy. 2017. The Importance of Verbal \& Non Verbal Communication. Retrieved 1 September 2017 from http://www.livestrong.com/article/156961-the-importance-of-verbal-non-verbal-communication.

[12] Mulyana, Dedy. 2001. Metodologi Penelitian Kualitatif. Paradigma Baru IImu Komunikasi dan IImu Sosial Lainnya, Bandung : Remaja Rosdakarya.

[13] Suciasih, Ciantini. 2003. Pola Komunikasi Anak Tunarungu: Studi Etnografi Komunikasi Pada Keterampilan Interaksi Anak Tuanrungu di Sekolah Luar Biasa Bagian B Yayasan Penyelenggaraan Pendidikan dan Pengajaran Bagi Anak-anak Tunarungu. In Kuswarno, Engkus. 2004. Dunia Simbolik Pengemis Kota Bandung, Studi tentang Konstruksi Sosial dan Manajemen Komunikasi Pengemis di Kota Bandung. Disertasi Program Pasca Sarjana Universitas Padjadjaran. Bandung. Pp :39 